\title{
PROCESSOS CRIATIVOS EM HISTÓRIA EM QUADRINHOS: \\ DESCRIÇÃO DAS INTERAÇÕES ENTRE ROTEIRISTA, \\ DESENHISTAS E LEITOR
}

Matheus Moura

\section{Resumo}

Este artigo versa quanto ao processo criativo coletivo em histórias em quadrinhos (HQs). São destacados quatro trabalhos distintos, produzidos por mim, em parceria com diversos autores. A proposta, então, é a descrição e análise dos processos criativos envolvidos, tendo como base estudos realizados por artistas, como Fayga Ostrower e psicanalistas, como Rollo May; dentre outros. O intuito é mapear e discutir os processos criativos dos autores, como eles se relacionam para construir um sentido comum e como as histórias em quadrinhos autorais se encaixam dentro do conceito de produto artístico. Observamos que, como realização espontânea e conceitual, as HQs são objetos de arte tanto quanto outras manifestações humanas, separadas apenas por interpretações limitantes, uma vez que elas exigem igual envolvimento do autor para com o fazer.

Palavras-chave

Histórias em quadrinhos; processos criativos, autorialidade

\section{Abstract}

This article covers the collective creative process in comics (HQs). Four different works are highlighted, produced by me, in partnership with several authors. The propose, then, is the creation and analisis of the envolved creative process, considering studies made by artistis, such as Fayga Ostrower and psicanalists, like Rollo May; between others. The intuit is to map and discuss the creative process of the authors, how they relate with each other to create a common sense and how the authorial comics matches the artistic product concept. We observe that, as spontaneous and conceitual realizations, the HQs are object of art as well as other human manifestations, separated only by limitant interpretations, once they require equal involvement of the author to so.

Keywords

Comics, Creative Process, authoriality 
A obra de arte provoca, toca, incita. Ela exerce um fascínio próprio perante o outro aquele que frui. Tão misterioso quanto os poderes da obra de arte é o seu próprio fazer. O ato criador de dar forma gera algo que faz parte do íntimo do indivíduo realizador. A partir dessa manifestação ele se expressa e se posiciona perante o mundo. É o brincar, como deixa claro a artista e pesquisadora Cecília A. Salles (2009), que motiva e recompensa todos os momentos de angústia e mal estar gerados pelo fervilhar de emoções que se agitam no amago do artista. Rollo May diria que é a coragem de criar (1982).

Motivados pelas inquietudes do fazer artístico, temos como ponto de partida para esse artigo os processos criativos envolvidos no fazer de histórias em quadrinhos (HQs). No entanto, não são histórias ordinárias. Ao contrário, são HQs que extrapolam o sentido comum da mídia - de ser produto da indústria cultural. Esses quadrinhos, no caso, se encaixam no subgênero chamado poético-filosófico. O pesquisador Elydio dos Santos Neto, que realizou, em 2010, o pós-doutoramento As histórias em quadrinhos poético-filosóficas no Brasil: Origem e estudo dos principais autores numa perspectiva das interfaces educação, arte e comunicação, determina três características para identificarmos esses quadrinhos: serem histórias necessariamente feitas para incitar o leitor a pensar; serem realizadas num formato típico do trabalho nacional galgado na audácia e coragem de inovar, com soluções para a limitação de espaço físico; e terem em seu bojo a experimentação vanguardista de forma e conteúdo (SANTOS NETO, 2010, p. 42).

De uma maneira ou de outra, todas as histórias foco dessa pesquisa se encaixam nas características determinadas pelo pesquisador. Mais ainda, se enquadram também no que entendemos como produto artístico. Para Scott McCloud, arte é "a maneira de afirmarmos nossa identidade como indivíduos e sair dos papéis pequenos que a natureza nos atribuiu" (2005, p. 166). Contudo essa definição nos parece por demais ampla e, por isso, acreditamos não atender de fato ao que é constituído como arte. Para tanto, propomos restringir esse conceito para: a expressão que, de uma maneira ou de outra, acaba por reter o próprio autor enquanto realização. Ou seja, entendemos como objeto artístico contemporâneo a manifestação humana que possui conceito, identidade e abertura para múltiplas interpretações. Justificamos essa adoção por não acreditarmos que se deva traçar uma historiografia dos quadrinhos calcada na história da arte, a qual já carrega seus 
próprios cânones, instituições, movimentos e linha cronológica tão bem definida. Isso não quer dizer que negamos a história da arte, pelo contrário.

Dentro desse nosso conceito de arte na contemporaneidade separamos os produtos pasteurizados, feitos apenas como objeto de consumo, vazios de significados e desprovidos de conceito. Seja esse produto um artesanato regional, ou a produção de peças industriais. Ressalvas a parte, o artesanato, apesar de ser uma microprodução em massa, pode sim possuir trabalhos conceituais e que carreguem a identidade do artesão.

Além disso, a partir do que entendemos como arte fica melhor delineada a linha que separa as histórias em quadrinhos "comerciais" das "artísticas". As primeiras, podemos dizer que se referem por exemplo aos super-heróis, sejam estadunidense, brasileiros, árabes etc - ou ainda a personagens e cenários pertencentes às grandes corporações. Como premissa, esse tipo de quadrinho prima mais pelo produto do que pelo autor - para termos uma base: sempre foi negado a Carl Barks (1901-2000), o renomado autor dos estúdios Disney, o direito de assinar suas próprias histórias. Nesses quadrinhos comerciais, o mote geral são aventuras limitadas a retratarem a vida de uma personagem ou grupo de heróis, por anos a fio. O Superman, considerado o pioneiro do gênero, foi publicado pela primeira vez em 1938 na revista Action Comics \# 1, e resiste até hoje como um jovem sempre a passar por reformulações para se adaptar às novas gerações de leitores. Artistas vão, personagem fica. Fez escola e deu subsídio para uma infinidade de cópias e similares.

Exemplos que validam essa questão são vários. Em recente entrevista ao site especializado Fast Company Co.Create, Jim Lee, reconhecido desenhista comercial de comics, ao falar da recém badalada continuação de Watchmen declarou que:

Esses universos evoluem e são desenvolvidos através de muitos criadores ao longo de várias gerações. O influxo de novas histórias é essencial para manter esses universos relevantes, atuais e vivos. Watchmen é uma pedra angular tanto na história da editora $D C$ Comics quanto para o seu futuro (...) Como editores, estaríamos sendo negligentes em não expandir e explorar esses personagens e suas histórias. Estamos empenhados em ser um dos líderes dessa indústria, o que significa tomar decisões criativas audaciosas (LEE, 2012, s/p - grifos nossos). 
Mesmo que essas "decisões criativas audaciosas" sejam anular por completo o - se não os dois, ao menos o principal - autor original, Alan Moore, o qual chegou a dizer possuir aversão a própria obra original devido a todo ocorrido. "Minha reação é um certo desprezo. Está além da raiva, é quase tragicômico. É a força do comércio sobre a arte. Estou orgulhoso do trabalho que fiz em Watchmen, mas está rodeado de uma nuvem tóxica de memórias e não gostaria de passar por ela novamente" (MOORE, 2012, s/p). Nos quadrinhos autorais isso não existe. Seriam esses os ditos quadrinhos de arte, ou quadrinhos de autor - como melhor ficaram conhecidos. Apesar de que a obra original citada, Watchmen, ser, sim, um trabalho autoral, essa nova, e polêmica, continuação intitulada Before Watchmen (em tradução livre: Antes de Watchmen) não é.

Até porque os quadrinhos autorais sobrevivem apenas pela força e vontade de seus criadores - e não de empresas. É famoso o exemplo de Ken Parker, fumetti italiano criado por Giancarlo Berardi (escritor) e Ivo Milazzo (desenhos), em 1974 e publicado pela editora Bonelli Comics. Ao todo foram lançadas 53 edições da série, que só deixou de ser publicada por questões editoriais. Na época a revista era sucesso de público sendo aclamada até hoje como um marco nas histórias de faroeste. Isso, no caso, não ocorreria com personagens da Marvel, ou da DC, os quais são propriedades das empresas que controlam e regulam as histórias, limitando a atuação da equipe criativa. Se os envolvidos com o projeto tiverem algum problema editorial com a empresa, serão substituídos em detrimento de outros mais suscetíveis a seus ditames - como ocorreu entre Alan Moore ${ }^{1}$ e a DC Comics.

Para Andraus, a questão dos quadrinhos de autor funciona da mesma forma que no cinema, quando se fala de filmes de autores e comerciais (2009, p.52). Os primeiros têm relevância enquanto manifestação artístico-humana. Já os segundos não, são desprovidos dessa característica, servindo só ao entretenimento. McCloud,

1 É notória a rusga entre Alan Moore e a gigante DC Comics. A briga começou por conta dos direitos autorais sobre a história Watchmen de autoria de Moore feita em parceria com Dave Gibbons e publicada entre 1986 e 1987. Cansado das constantes trapaças da indústria. Moore hoje se recusa a trabalhar com grandes empresas, negando até mesmo a menção de seu nome nas adaptações para o cinema de suas obras, as quais tiveram os direitos usurpados pelos contratos leoninos das editoras do mainstream. 
em termos de quadrinhos, diz que ler gibis comerciais é como morder uma volumosa e vermelha maçã, de encher os olhos, mas oca (2005, p.171). Ao dar continuidade ao exemplo, o pesquisador define "seis passos" para a realização de uma HQ: 1) Ideia/objetivo; 2) Forma; 3) Idioma; 4) Estrutura; 5) Habilidade; 6) Superfície (2005, p. 170). O vermelho e o volume da maçã, mencionados por McCloud, referem-se ao sexto passo: a superfície. O oco, então, significa que essa história, no caso, é desprovida dos cinco passos restantes.

Assim, para McCloud, o quadrinho arte seria aquele que circunscreve melhor esses passos, a acumular todas as etapas e voltando-se, cada vez mais, para o próprio autor: "ideia/objetivo e forma". Quanto menos desses aspectos tiver, mais superficial, banal e massiva será a manifestação cultural, seja ela quadrinhos, cinema, pintura etc (Idem, ibdem, p.171). Os dois primeiros níveis, ideia/objetivo e forma, são os mais profundos e importantes desses "passos". De acordo com McCloud, o autor que escolhe seguir pelo caminho da ideia "sua arte vira uma ferramenta. E a força dessa arte vai depender da força das ideias dentro dela" (2005, p.179). Enquanto que se for escolhida a forma, o autor passaria a ser "um explorador. Sua meta: descobrir tudo sobre a forma artística" (Idem, ibdem, p. 179).

Com essa distinção encaramos as histórias em quadrinhos como duas frentes bem definidas: os passíveis de serem reconhecidos como objetos artísticos, os quais merecem atenção e pesquisas à altura, e os comerciais: frutos da cultura de massa, insossos e irrelevantes enquanto manifestação humana e, portanto, devem ser tratados como tal. Apesar de tudo, é importante levantar mais esta ressalva: como no caso do artesanato, o mainstream, por vezes, produz obras seminais tão profundas ou mais que muitos quadrinhos "independentes". A razão disso é que, no decorrer do tempo, vários autores conseguem galgar seu espaço na indústria e, assim, manter - se não intacta ao menos em alto grau - sua liberdade artística, a criarem assim verdadeiras obras autorais.

Tendo esses aspectos em mente propomos analisar nosso próprio processo criativo, enquanto roteirista, em parceria com vários outros autores - nos desenhos. O que nos motiva é a busca pela validação de aspectos inerentes a criatividade genuína, tratada por artistas pesquisadores como Fayga Ostrower (1972), Stephen Nachmanovitch (1993), Rollo May (1982) e tantos outros, dentro do fazer das 
histórias em quadrinhos. Além disso, visamos participar das discussões quanto à interação dos processos criativos em diferentes níveis de relação. Como por exemplo, no primeiro caso descrito, o da história Frígida. Essa, de maneira inusitada acabou por incitar o processo criativo de uma leitora, que se sentiu impelida a "responder" nossa história, subvertendo a obra original. Outro caso é da HQ Agir sem Ver, em que partimos de um processo criativo "as cegas".

Por ser uma análise pessoal, de produção própria, a partir daqui usarei a primeira pessoa do singular para me referir a mim, especificamente. Em contrapartida, o plural será usado para me referir a ambos os autores - desenhista e roteirista.

\section{1 - Frígida x Reinterpretação}

Dentre as várias histórias que já realizei, uma que merece atenção especial é Frígida, escrita por mim em 2007 e ilustrada por Rosemário Souza entre 2007 e 2008. Apesar de pronta há algum tempo, só decidimos publicá-la, na revista independente Camiño di Rato \# 3, em 2010. A protelação em publicá-la se deveu ao teor da história ser, podemos dizer, por demais provocador. Tanto que não tardou e tivemos a confirmação disso, a partir de um resultado inesperado: uma história em quadrinhos em resposta à Frígida.

Essa resposta é intitulada "Necrofilia" ou "Uma reinterpretação de 'Frígida"', feita por Carmilla le Fanu - obviamente um pseudônimo. Nela a autora inverte os papéis dos personagens originais, realocando-os em cenários diferentes. 0 interessante é que, por meio do que criamos, com base em minha própria experiência particular, Carmilla realizou sua história tendo sido tocada e motivada por seu próprio repertório construído ao longo da vida.

A metodologia utilizada aqui será uma análise crítica da HQ criada por nós Frígida - e a feita por Carmilla le Fanu, identificando semelhanças, polaridades, tensões e como elas funcionaram como elementos básicos para reforçarem a mensagem da autora. Com isso serão identificados os elementos-chave que "tocaram" o inconsciente de Fanu levando-a a criar sua resposta. Feito isso, o cruzamento entre as teorias apresentadas embasará os possíveis resultados. 
Como conclusão prévia tem-se, principalmente, o seguinte: o processo criativo da autora passa, invariavelmente pelo nosso, sendo ele carregado de pré conceitos de gênero e sociais, porém ao mesmo tempo em que nega Frígida, Le Fanu a legitima.

\section{Frígida}

A história em quadrinhos Frígida foi escrita por mim, Matheus Moura, em 2007 como resultado de um sonho e, mais tarde, ilustrada por Rosemário Souza. Essa foi a primeira história em que trabalhamos juntos. Como mencionamos no artigo apresentado na terceira edição do Seminário Nacional de Pesquisa em Cultura Visual (SILVA, 2010, p. 1.664), muito da nossa produção particular como roteirista se dá em sonho ou momentos antes de dormir. Como visto a partir de May (1982), Ostrower (1977), Nachmanovitch (1993) e Kneller (1972), esse estado de descanso e o surgimento de ideias é natural do processo criativo.

O conceito, propriamente dito, de Frígida surgiu da vontade de construir uma HQ típica de horror. Durante anos, nos quadrinhos, principalmente durante a década de 1950 (LUIZ, 2010, p. 01) e, posteriormente entre 1960 e 1970 (DANTON, 2011, p. 01), foi possível ter acesso a inúmeras histórias de terror, sempre escritas e ilustradas de diversas maneiras. Os temas variavam da mais comum e banal superstição ao escatológico. Dentre esses múltiplos caminhos do horror há um corriqueiro que possui uma carga emotiva bastante forte: a necrofilia. Talvez devido à sacralização do corpo, imposta pela religião em conjunto com o medo da morte, independente disso, o fato é que a necrofilia é repulsiva. Frígida trata disso.

Nosso intuito com essa HQ foi justamente suscitar no leitor as mais sortidas emoções, indo da repulsa a indignação e, principalmente, surpresa. Essa última devido ao uso do recurso narrativo, chamado por Gian Danton, "final surpresa" (DANTON, 2008, p.63). Esse, no caso, caracteriza-se, como diz o nome, por um final que surpreende o leitor. Assim, trabalhamos em Frígida de maneira a levar o leitor, no decorrer da leitura da HQ, a não perceber que a mulher em questão está morta. O leitor, então, só se dá conta disso ao virar a página e ler o final da história. Nesse ponto, toda a carga emotiva colocada nos pensamentos da personagem principal - pensamento que, da forma como foi escrito, pode tanto ser entendido como do homem quanto da mulher - é invertida, levando ao leitor, que antes se identificava com o ocorrido, a repudiar o ato. 


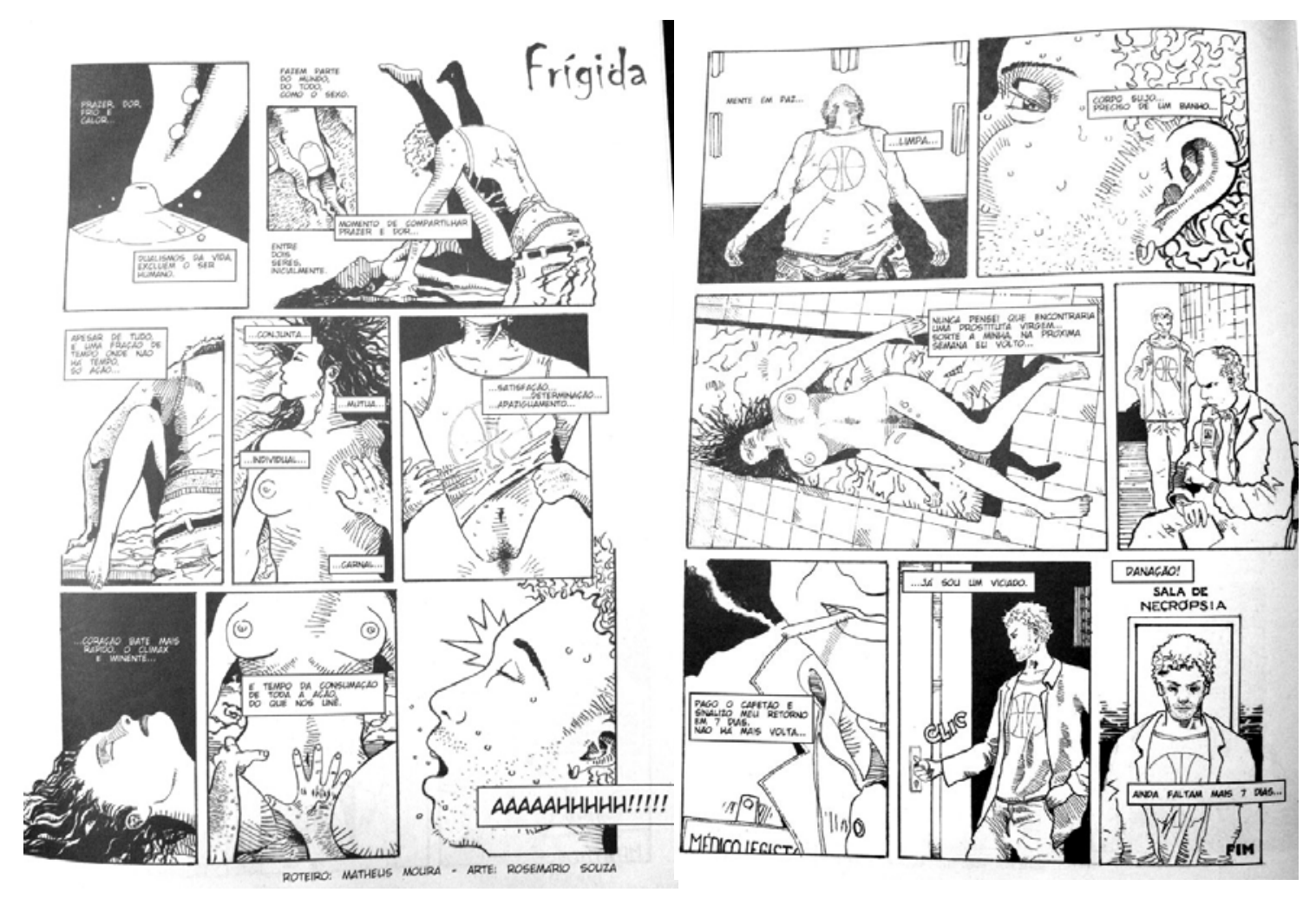

Figura 1: Frígida

Fonte: Revista Camiño di Rato \# 3, 2010.

O título, Frígida, faz menção a algo frio, duro, seco, insensível. Na linguagem figurada indica a mulher que não sente vontade e/ou prazer sexual (AULETE, 2008). Todas essas qualidades estão presentes na "prostituta virgem" - na verdade uma mulher que morreu virgem e que, na história, se torna objeto sexual. Ao partir da própria subjetividade ao criar a trama, Frígida dialoga com minha experiência particular (Matheus Moura) em ter-me relacionado, por certo período, com uma mulher que pode-se chamar de frígida, ou seja, não possuía apetite sexual. A brincadeira, então, consiste em apresentar como, ao mesmo tempo, algo pode ser prazeroso e requerido por um(s) em contrapartida do indesejável, evitado ou mesmo indiferente por outro(s). 

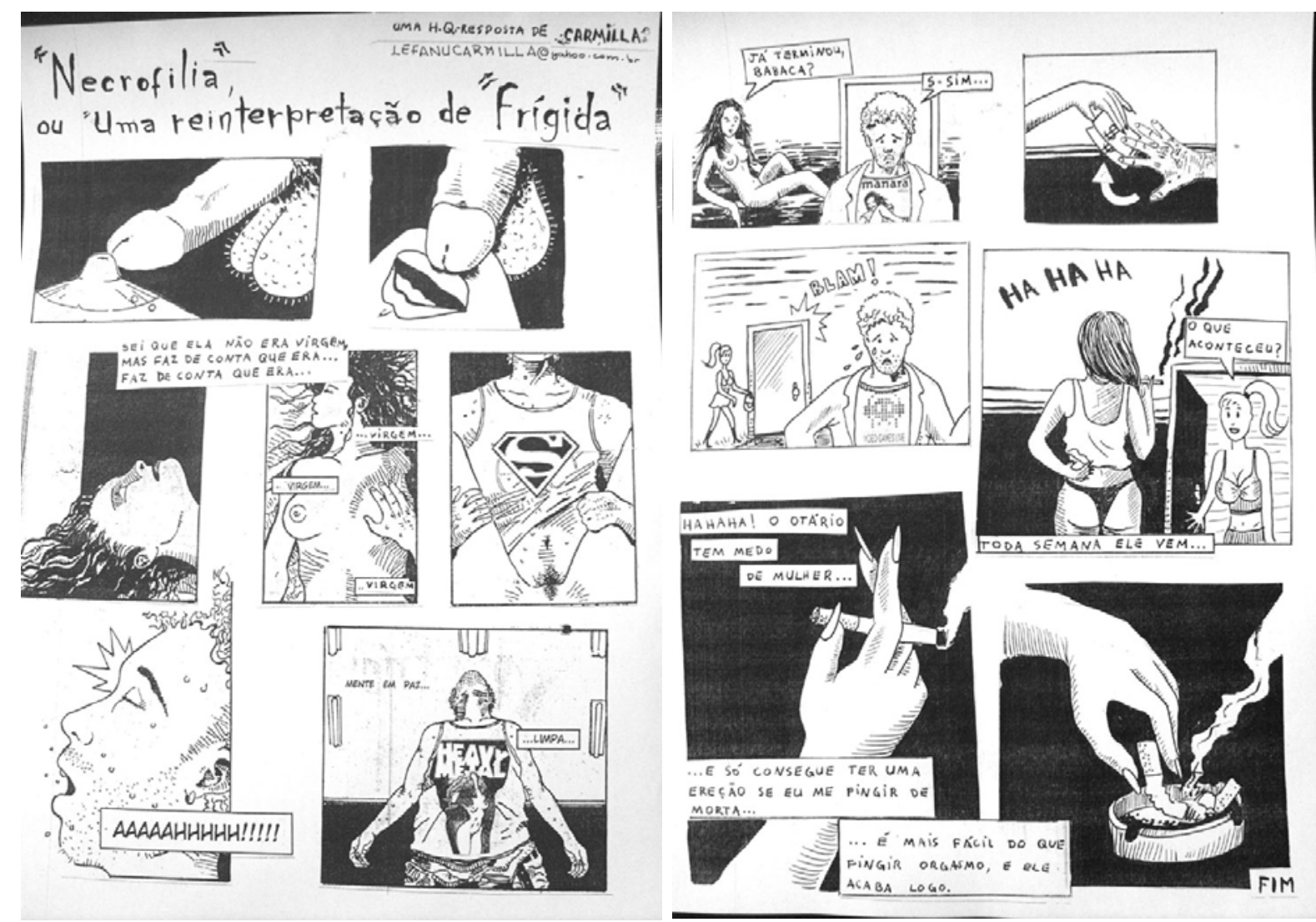

Figura 2: Necrofilia ou Uma Reinterpretação de Frígida

Fonte: http://carmillalefanu.blogspot.com/, 2010.

Escolhemos o termo androfobia como título dessa parte do texto por se referir a "aversão ou horror ao sexo masculino" (AULETE, 2008). Essa parece ser uma questão central para a autora, Carmilla le Fanu - como já dito, um pseudônimo. O nome escolhido por ela, por si só já deixa algumas pistas sobre suas formas de ver o mundo: Carmilla é considerada a primeira vampira da literatura, surgida em 1872, escrita pelo irlandês Joseph Thomas Sheridan Le Fanu (1814 - 1873). No livro, Carmilla é uma mulher fatal que usa de astúcia para se aproximar de suas vítimas. Ela forja, juntamente com alguns comparsas, uma situação em que acaba por ser convidada a passar alguns dias na casa de um generoso desconhecido. Assim, ela começa as investidas noturnas. Toda as noites, ela ataca pelo sonho. Com isso ela suga a energia (sangue) da vítima lentamente. É interessante notar que Carmilla, além de ser a primeira vampira, é a primeira vampira lésbica da literatura. Ou seja, ela só ataca mulheres. 
Assim, é fácil entender quando a autora da resposta diz, no texto publicado no blog criado exclusivamente para a HQ-resposta, "a verdadeira mensagem passada pelos autores [...] foi de uns pobres homens amedrontados pela verdadeira força feminina, que vem se mostrando cada vez maior" (FANU, 2010), como sendo uma manifestação feminista. Outro ponto que merece ser destacado para a tentativa visto que não a conhecemos e podemos apenas conjeturar - de traçar parte do perfil da personalidade da autora é quando ela diz:

Acho o abuso sexual abominável em todas as suas formas, e acho doentio quando isso é mostrado como foi na estória "Frígida", com a clara intenção de ser uma estória erótica, sensual (para os homens, óbvio; creio que para a maioria das mulheres a estória cause mal estar e, talvez, indignação, não pelas imagens, que nada tenho contra a pornografia saudável, mas pelo conceito que pretende passar: a eroticidade de um abuso sexual e o desejo por uma mulher imóvel, submissa, servil da maneira máxima que se poderia ser) (FANU, 2010).

Ela apresenta os homens, de maneira geral, e principalmente os autores de Frígida, como pervertidos sexualmente e tendo que, a todo custo, demonstrar superioridade de gênero. Algo que, dentro de nossa concepção autoral, não é verdadeiro. Isso, de maneira precisa, indica tendências - se não efetivas - do mais puro feminismo radical - feminismo antagonista do machismo, ou seja, o do tipo que tende a diminuir e, até mesmo, desrespeitar o sexo masculino. A pesquisadora Maria Filomena Gregori, no artigo "Prazer e perigo: notas sobre feminismo, sex-shops e S/M" (GREGORI, 2004), descreve brevemente como se dá essa visão limitada do posicionamento da mulher na sociedade:

Os grupos anti-pornografia - que fazem parte do que os estudiosos do campo denominam como feminismo radical - eram compostos por mulheres identificadas com uma parcela da comunidade feminista lésbica que não apenas rejeitava o sexo heterossexual por uma questão de escolha sexual, mas como conseqüência de uma leitura particularmente determinística sobre a dinâmica de poder das relações heterossexuais. Catharine Mackinnon, apresenta uma análise das relações sexuais como sendo estruturadas pela subordinação de tal modo que os atos de dominação sexual constituem o significado social do "homem", e a condição de submissão o significado social da "mulher". Esse determinismo rígido, segundo Judith Butler (1997), traz, pelo menos, duas implicações: em primeiro lugar, a noção de que toda relação de poder é uma relação de 
dominação, toda relação de gênero, pois, só pode ser interpretada por esse crivo; implica também a justaposição da sexualidade ao gênero - entendido a partir de posições rígidas e simplificadas do poder - associando-o, sem maior exame, ao "homem" e à "mulher". O feminismo radical hasteou sua bandeira contra instituições heterossexuais, como a pornografia, tomando-a como um exemplar da violência e do perigo contra as mulheres. Além da pornografia, o movimento definiu outros alvos: o sado-masoquismo, a prostituição, a pedofilia, a promiscuidade sexual" (GREGORI, 2004) [grifo nosso].

A abordagem do feminismo aqui se faz necessária por ser essa linha condutora da interpretação de Carmilla le Fanu, não havendo como dissociar uma coisa da outra. Essa questão é tão latente para a autora que a todo momento relaciona - inconscientemente ou não - o feminismo com sua resposta, como quando ela fala sobre a questão da virgindade abordada na $\mathrm{HQ}$ e o fato da mulher estar morta:

A frase que o personagem pensa na segunda página, 'nunca pensei que encontraria uma prostituta virgem' também me levou a pensar sobre a ridícula valorização da virgindade feminina, ainda nos dias de hoje, valorização essa iniciada pela igreja cristã com sua implacável perseguição ao sexo como forma de controle de consciências [...] O incrível é esse conceito todo sobreviver ainda nos dias atuais. [...] Chamo ainda a atenção para o título da estória: como a mulher-defunta não reage, ela é frígida, palavra provavelmente inventada por algum macho ruim de cama que nunca conseguiu satisfazer ou sequer excitar uma mulher" (FANU, 2010).

Com relação ao processo criativo da HQ-resposta, propriamente dito, a autora usou de colagens - por meio de fotocópias e recortes da Frígida original - aliadas aos seus próprios traços para complementar o sentido. Ela descreve esse processo no blog. Para traçar melhor as significações dadas pela autora, ela incluiu alguns símbolos que podem ser vistos estampados na camisa do personagem principal de Frígida. Fanu explica: 
Na minha "estória-crítica", ou "hq-resposta", como denominei, o desejo do homem em ser o poderoso diante da submissão feminina é representado pelo símbolo do super-homem na camiseta enquanto ele supostamente abusa da mulher. À medida que a estória se desenvolve o desenho muda, primeiro para imagens de mulheres nuas, representando a idealização da mulher-objeto, e finalmente para uma imagem de videogame, quando ele já está assustado e a caminho de casa, prestes a se fechar novamente em seu mundinho" (FANU, 2010).

\section{Swing}

A expressão é inglesa mas já foi incorporada no vocabulário nacional tendo um significado em comum: "prática sexual baseada na troca de parceiros e de que participam dois ou mais casais" (AULETE, 2008, página). No que concerne ao processo criativo das duas HQs, a situação ilustra metaforicamente a "troca de casais" proposta aqui. Assim como Fanu toma a liberdade de trabalhar com nossa história, faço o mesmo ao reinterpretar sua resposta por meu olhar autoral, masculino e individual. Um verdadeiro swing.

Voltando a May (1982), quando ele distingue a criatividade genuína da escapista, pode-se enquadrar a "estória-crítica" de Fanu como esta última. Como coloca May, o ponto principal que separa uma da outra é a ausência de encontro, ou seja, não existe engajamento com o ato de criar. Ele surge mais como uma força a exteriorizar algo interno do indivíduo, funcionando como válvula de escape e alívio.

Essa é a essência da arte escapista. Tudo está presente, menos o encontro. É também o fator central da arte exibicionista - chamada por Rank de artiste manqué. Não se pode fazer uma distinção válida admitindo a existência da arte neurótica e da arte normal. Quem poderia julgar a diferença? Podemos dizer apenas que na forma exibicionista e escapista da criatividade não há encontro real, não existe engajamento com a realidade. [...] O ponto mais importante, porém, é que o assunto nada tem a ver com criatividade" (MAY, 1982, p. 34).

Da maneira como May coloca, a "hq-resposta" de Fanu acaba por tratar simplesmente de indignação insuflada por certos aspectos ideológicos radicais da autora diferindo de nossa proposta como autores ao escrever e ilustrar Frígida. A cultura visual explica bem essa inter-relação de narrativas entre indivíduo e estímulos externos . 
[...] um dos pontos essenciais à cultura visual [...] está exatamente em perceber que a imagem só encontra significado nas experiências que produzem posições subjetivas. Isso significa compreender que as relações determinam seus termos, e não o contrário. Ou seja: cada individualidade é o lugar das relações onde se dá a experiência produtora de significados, de narrativas. Como diz Certeau, 'o enfoque da cultura começa onde o homem ordinário se torna o narrador, quando define o lugar (comum) do discurso e o espaço (anônimo) de seu desenvolvimento' (1994, p. 53)" (MELO, 2008, p.40).

Isso justifica afirmar que, quando Fanu interpreta nossa história e atribui um "sentido real" ao que produzimos - respondendo Frígida e tendo ela "a verdadeira mensagem passada pelos autores..." - a autora nada mais faz do que se expor. Expor seus próprios preconceitos, relações com o mundo e consigo mesma. Exemplo disso tomamos da própria hq-resposta quando ela, ao se colocar como a mulher que revida, faz dela as suas palavras ao dizer: "Já terminou babaca?" e "O otário tem medo de mulher" [grifos nossos], indicando clara posição de ataque ao masculino, com palavras de baixo calão gratuitas e desnecessárias, aproveitando-se do anonimato. Sendo este muito bem exteriorizado na adoção de pseudônimo e publicação em blog.

Claro que Frígida, desde o início, é sim uma história que suscita os mais variados sentimentos. Muitos deles, é verdade, são negativos como repulsa, indignação, nojo. Por seu caráter inusitado, ela provoca sentimentos pungentes nos leitores, assim é válida toda e qualquer (re)interpretação ou resposta a ela que se tenha, justamente por ela abrir-se às subjetividades múltiplas. O que fizemos aqui, então, foi uma tentativa de analisar brevemente os dois trabalhos quanto à suas motivações subjetivas e seus processos de criação.

\section{2 - O Encontro}

A expressão, Encontro, é uma referência direta ao conceito de encontro dado por Rollo May (1982). Ao mesmo tempo, indica ainda outros dois encontros: o meu (enquanto autor) com o insigh; e da personagem principal da história com seu interlocutor. Como de costume, minha parte na criação da história se limita ao roteiro e/ou ideia geral, sendo concebido em texto para, só assim, ser transformado em 
imagens - nesse caso desenhadas por Guilherme E Silveira. O interessante desse texto, e da criação dessa história em específico, é que converge ao meu contexto particular de estudo e pesquisa na época.

O referido roteiro é de uma História em Quadrinhos do gênero poéticofilosófico com o acréscimo de um pouco de terror. Na história, durante uma noite chuvosa, um homem persegue uma mulher por entre becos e corredores estreitos e opressores. No final da perseguição, quando a mulher se acha livre, ela acaba por se deparar com algo não mostrado. O homem, atônito, se direciona para onde a mulher sumiu e lá vê uma espécie de casa - na verdade um cômodo simples localizado ao final do beco. No interior desse cômodo o perseguidor encontra uma estranha criatura. Desse insólito encontro surge o clímax da história, nele há um diálogo entre o homem e a criatura. Fim. Pode-se dizer que essa história, na verdade, não possui um clímax, propriamente dito, uma vez que o diálogo corta a ação criando assim uma espécie de anticlímax narrativo.

Outro fato comum no nosso processo de criação é o insight ocorrer em sonho e/ou no momento antecedente ao primeiro estágio de dormência. A criação dessa inusitada história teve, então, como início um "pesadelo" - as aspas se referem ao fato de eu, como escritor, não ver os pesadelos como partes indesejáveis dos sonhos, muito pelo contrário, como demonstramos aqui, eles são fontes inesgotáveis de inspiração. Nesse sonho, vimos uma mulher que foge de algo não mostrado. Logo, eu (personagem no sonho) estou em um local sujo, feio, como o descrito no roteiro, e entro em uma casa. Nela, há um monstro humanoide-molúsco que diz coisas que não possíveis serem recordadas. Depois desse encontro macabro, ao acordamos, foi anotado tudo que foi possível lembrar (principalmente a ideia do monstro e o local em que ele se encontrava). Depois, deixamos a ideia no papel, nem mesmo foi digitada no computador, como de costume.

Os dias passaram e mais de seis meses já haviam transcorrido desde o pesadelo. No entanto, durante esse período, de tempos em tempos nos ocorriam lembranças da criatura e pensamentos com o intuito de desenvolver algo com ela no caso, uma história. 


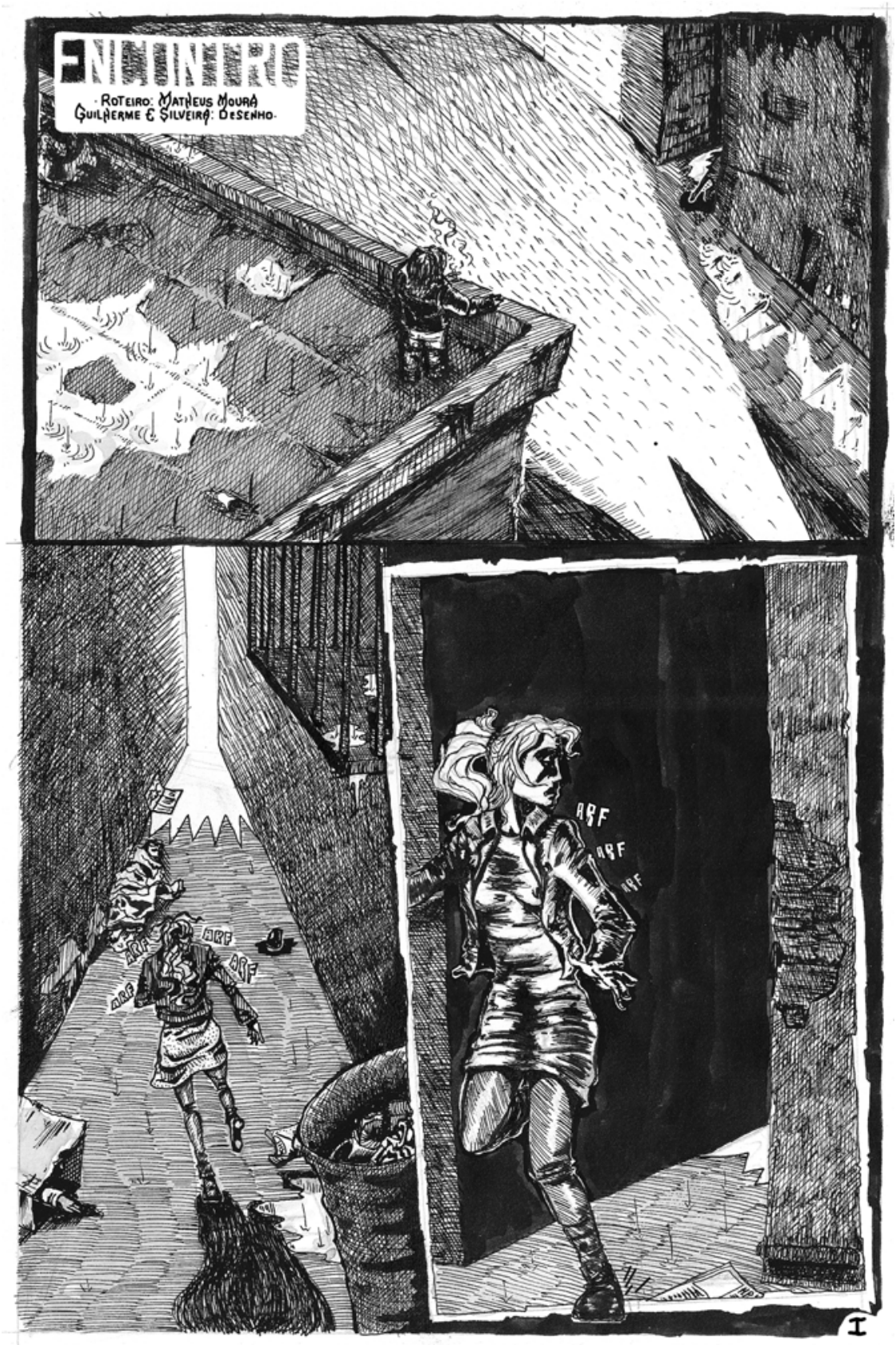




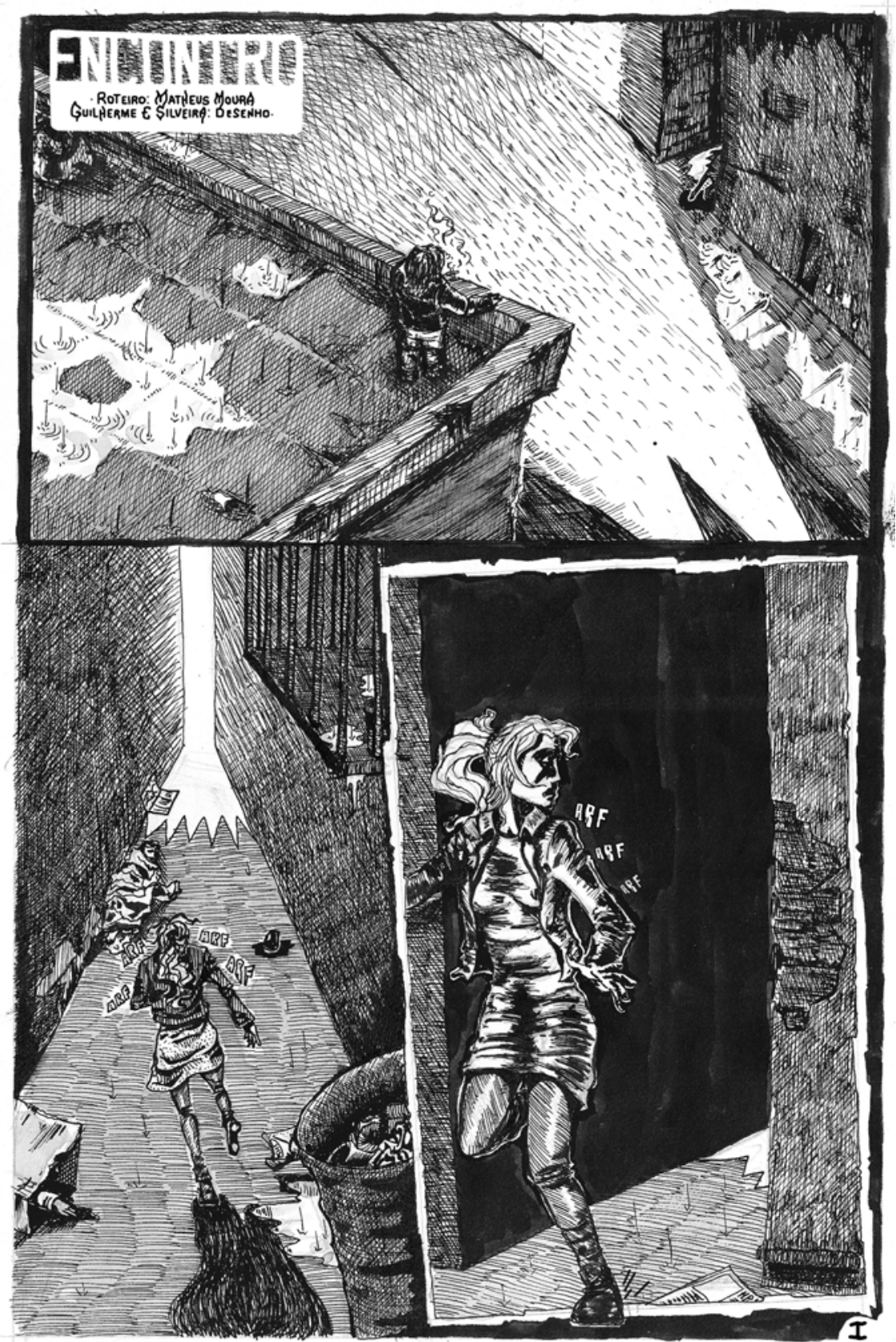

Figura 3: Encontro, p.2

Fonte: zine Encontro.

No dia 7 de abril de 2010, dei início a leitura do livro A Coragem de Criar, escrito pelo psicanalista, Rollo May. Na primeira metade da publicação, Rollo trata principalmente das etapas mentais e comportamentais de criação, além de definir o que venha a ser criatividade e a coragem do ato de criar. A maneira como o artista age, pensa e sente momentos antes do "encontro", ou seja, do surgimento do ato criativo, que, como já dissemos antes, levará o artista ao seu próprio "mundo 
objetivo". Para não corrermos o risco de ficarmos repetitivo, seremos breve nas ponderações quanto ao pensamento de May nessa parte. Porém, é possível recorrer ao tema a partir da página 35 o qual faz parte da discussão sobre criatividade.

O "encontro", então, mencionado logo acima e descrito por May (1982), é quando o artista se depara com o que lhe impele a criar. A grosso modo seria a inspiração. No nosso caso, o encontro foi no sonho. No livro, May até mesmo cita um exemplo de um professor de Nova lorque que, por meio de sonho, teve um encontro que Ihe rendeu o prêmio Nobel (MAY, 1982, p. 44). Para o psicanalista, o encontro está como o princípio do processo criativo, ou seja, o nosso havia tido início há vários meses, quando despertamos de um pesadelo e foram anotados seus pontos principais.

É interessante notar que o encontro não necessariamente é realizado de modo consciente. O nosso, por exemplo, irrompeu do sonho. $E$ isso não o descaracteriza ou diminui perante algo previamente analisado e estudado. Como diz May, "a resolução de problemas que nos vêm em devaneios ou sonhos não são produtos do acaso" (MAY, 1982, p. 45). Pelo contrário, essas soluções, ou encontros, surgem em sonhos e momentos de descanso por terem sido antes trabalhadas mentalmente com grande dispêndio de energia (MAY, 1982, p. 45). Isso, então, determina o nível de compromisso individual com o próprio ato criativo, ou seja, com seu encontro. É por meio desse envolvimento que May distingue dois tipos básicos de criatividade: a escapista e a genuína (MAY, 1982, p. 42) - já discutidas.

\section{Encontro e ansiedade}

O autor do livro A Coragem de Criar (1982), Rollo May, destaca, ainda, quatro fatores do processo criativo: ansiedade; claridade; gestalt; e intuição. No meu caso específico, para a criação do referido roteiro, os quatro fatores foram muito bem delineados. Primeiro, durante a leitura do livro passamos a sentir uma certa inquietação. De acordo com que dávamos prosseguimento à leitura, mais essa ansiedade aumentava. Segundo, juntamente com a ansiedade passamos a prestar mais atenção ao que estava a nossa volta, principalmente ao livro e mãos, sua textura, cores, disposição das letras e tipografia. Terceiro, sentimos que uma peça, 
não muito bem definida acabara de se juntar a outra já formada, ou seja, a ideia que possuíamos da história, tirada de sonho/pesadelo e anotada em um bloco de papel. O quarto e último fator, estávamos em um momento de leitura (trabalho) e parcialmente disperso da leitura. Foi então que decidimos deixar a leitura de lado e pôr-nos a escrever.

Durante o processo de escrita, o texto fluiu com naturalidade. Parecia que já tínhamos a ideia toda na cabeça. Não precisamos nem ao menos recapitular o que havia sido escrito a respeito do sonho. Porém, ao final do texto houve um bloqueio. Havia chegado a um momento em que, assim como a mulher na história, estávamos sem saída. Sabíamos como devia terminar o conto, mas com o seu desenrolar nosso final, previamente concebido, agora era um estorvo, uma vez que ele nos limitava a desenvolvê-lo apropriadamente. Salvei o arquivo de texto e resolvemos espairecer e fomos comer algo. Ao nos afastar da frente do computador e a nos colocar novamente em um estado de repouso, subitamente um novo final, agora de acordo com o desenrolar da trama, irrompeu do inconsciente levando-nos a experimentar outro aspecto descrito por Rollo: a gratificação. "Regozijamo-nos por participar do que a física e outras ciências naturais chamam de uma experiência 'elegante"' (MAY, 1982, p. 60).

Essa descrição da experiência de construção da história, Encontro, é interessante por demonstrar bem como age os processos de criação na mente do indivíduo. A relação próxima, às vezes quase exata do descrito por May, passa por outro aspecto - que é chamado atenção pelo psicanalista russo L. S. Vygotsky (1982) - de que não se pode criar fora dos limites de seu próprio repertório. Em outras palavras, nosso método de criação para Encontro foi totalmente influenciado pelos estímulos gerados durante leitura do livro de May.

O desenhista, Guilherme E Silveira, corrobora esse ponto levantado quanto às influências e limitações de repertório. No relato escrito pelo artista - e publicado no fanzine Encontro, lançado em 2010 -, Silveira aponta como foi a construção e escolha para os elementos do último quadro da história: 
Ao produzir a tipografia da fala do monstro resolvi usar uma pequena referência/homenagem aos quadrinhos de Gazy Andraus, uma vez que esse autor trabalha não criando uma situação que mostra reflexão, mas sim direto com a reflexão, achei interessante usar uma tipografia com semelhanças a sua nesse personagem que é o elemento reflexivo da narrativa. (SILVEIRA, 2010, s/p)

Para finalizar a descrição do processo de criação desta história, acreditamos ser válido levantar a motivação da escolha de Silveira como ilustrador. A bem da verdade, primeiramente conversei com dois outros desenhistas (já parceiros em outras obras), Fábio Turbay e Abel, para ilustrarem, os dois juntos, o conto. Devido ao prazo curto (havia pouco mais de uma semana) e interesses particulares, decidi falar com Silveira. O interesse particular que mencionei é quanto ao âmbito acadêmico. Diferente dos dois primeiros, Silveira é acadêmico e, em 2012 ingressou no Mestrado em Letras da Unesp/São José do Rio Preto (SP), na linha de pesquisa História, Cultura e Literatura, com investigação voltada à "Narrativa Visual de Lourenço Mutarelli". Dessa forma, a motivação em realizar essa HQ foi ampliada pela possibilidade de apresentá-la no III Seminário Nacional de Pesquisa em Cultura Visual, promovido pela FAV/UFG e realizado em 2010. Tendo isso em mente, resolvemos deixar a cargo de Silveira a tarefa da ilustração até porque, de uma maneira ou de outra, ele iria se empenhar mais em fazer a história - por ter mais em jogo para ele - do que havia para os outros dois. Assim, retirei o pedido e responsabilidade de Turbay e Abel, voltando-a toda para Silveira, o qual, no final, ao meu ver, superou expectativas.

\section{3 - Agir sem Ver}

Diferente de Frígida e assim como Encontro, podemos inserir a história descrita a seguir como uma narrativa do gênero poético-filosófica por enquadrar-se nas três características propostas por Elydio dos Santos Neto (2010), além de deixar-se aberta para múltiplas interpretações e o principal: levar o leitor a pensar e a questionar. A história destacada, intitulada Agir sem Ver, foi escrita por mim, Matheus Moura, desenhada por Rosemário Souza e publicada originalmente na revista Camiño di Rato \# 2, em 2009, editada por nós dois. 


\section{O Processo}

O contexto em que surge Agir sem Ver é bastante inusitado. Antes dessa história eu e Rosemário Souza já havíamos trabalhado juntos em outras duas HQs: Frígida e viva a sociedade passiva!!!. Ambas publicadas também na revista Camiño di Rato, respectivamente, na terceira e na primeira edição. Souza relata que:

Para falar sobre Agir sem Ver, tenho que voltar um pouco no tempo, mais exatamente à época do início de minha parceria com o amigo e roteirista Matheus Moura, cerca de 3 anos atrás: ele me trouxe um roteiro de duas páginas, o qual desenhei, chamado "Frígida".

O resultado ficou satisfatório pra nós dois, na época. Olhando para ele hoje, vejo que ainda era um trabalho feito 'à moda antiga', sem muita experimentação... Então, tempos depois, criamos a Camiño di Rato, uma revista alternativa, onde poderíamos "brincar" com a linguagem gráfica, um laboratório para destilarmos nossas idéias.

Com esse intuito, pensei em fazer duas páginas de desenho e depois entregá-las ao Matheus, realizando o processo da Frígida às avessas. Ele escreveu o texto a partir das imagens prontas, isso tornou viva a sociedade passiva!!!.

Funcionou bem, mas... Ainda tímido. Queria ir mais além. Pensei no seguinte: eu faria quatro páginas de $\mathrm{HQ}$ e ele faria um texto para ser 'encaixado' nessas quatro páginas, sem ter visto nenhuma das imagens!" (SOUZA, 2010, p. 01)

Por minha vez, quando incumbido da tarefa de desenvolver um texto sem ter a noção das imagens, fiquei instigado. Foi então que percebi: não tendo nada concreto para dar início à narrativa acabei por ficar preso. A aparente liberdade de poder desenvolver o texto livremente, acabou por limitar minha criatividade ao formato pré estabelecido da história: quatro páginas de HQ. E isso desencadeou uma corrente de problemas: quatro páginas de HQ não são quatro páginas de texto. E assim por diante: Como a história estará disposta? Quantos quadros haverá por página? Vão haver quadros? Qual o gênero da HQ: ação, terror, drama, etc?

Foi então que percebi: eu só poderia contar com a dúvida. Ela foi o único ponto imutável no processo de criação do texto desta HQ. Decidi, então, levar esses questionamentos para o trabalho. O alvo escolhido foi o próprio ato de criar. Principalmente o de criar algo que não se sabe o que é, ou para o que é. 
Ao ler o relato de Souza senti que ele passou por uma experiência semelhante à minha ao desenhar a história a imaginar, por outro lado, aonde a trama iria dar. Ele descreve:

\begin{abstract}
Pois bem, de minha parte, tratei de criar uma cadeia de acontecimentos abstratos, em que uma figura ia 'se tornando' outra no decorrer das páginas. Fazia um quadro sem saber exatamente o que viria a seguir. Algo inadmissível a qualquer quadrinhista respeitador das regras básicas das Histórias (não só em quadrinhos): tenha sempre em mente o final antes de começar" (SOUZA, 2010, p. 01).
\end{abstract}

Inconscientemente, Souza acabou por impor-me o mesmo princípio a que se colocou: não "saber o que viria a seguir". O "mundo objetivo" (MAY, 1982), descrito por May, torna-se nítido aqui mais uma vez. É por meio dele que há a extrapolação do mundo físico palpável. É a formação do mundo interior do artista, aquele com que ele irá adentrar no momento de criação a extrapolar o sentido de mundo (MAY, 1982, p. 49) e da relação objeto-sujeito. Isso acaba por gerar a expressão daquilo que está guardado internamente no artista. Tendo a obra de arte influência do tempo-espaço da sociedade em que ocorre, essa influência, como não poderia deixar de ser, acaba por ter papel fundamental no desenvolvimento da história em quadrinhos Agir sem Ver. Ela age de maneira complementar em mim e no desenhista, a suscitar pontos em comuns do cotidiano de cada um. 

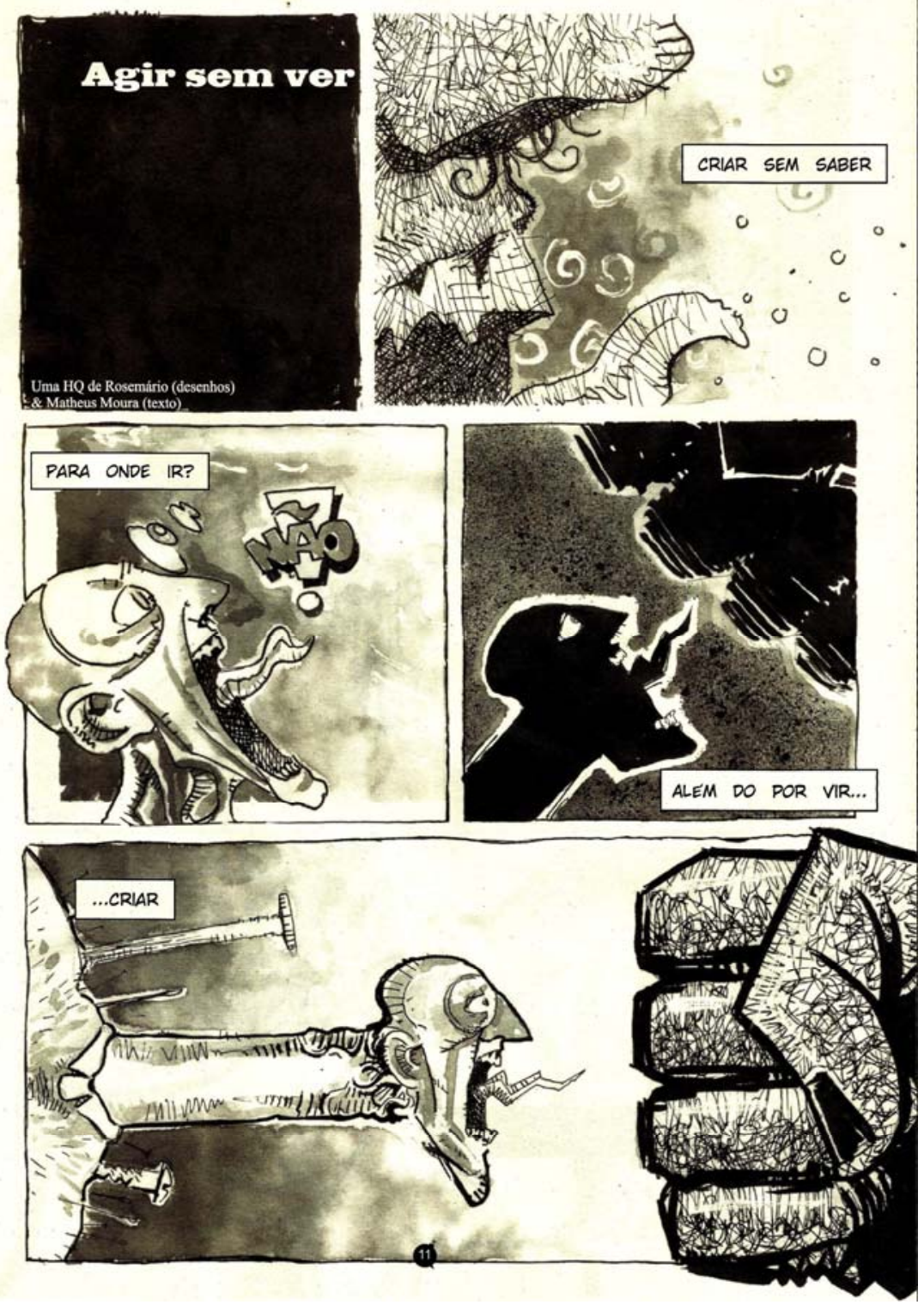

Figura 4: Agir sem Ver, p. 1

Fonte: Camiño di Rato \# 2.

O "encontro", ou a "musa", descrita por Stephen Nachmanovitch (1993, p. 43), impele o ato criador - independentemente do método (ou a falta dele) de cada um de nós (especialmente Moura e Souza). Assim, são justamente essas semelhanças que proporcionaram nossa criação conjunta, mesmo que separadamente - uma vez que nossas histórias tiveram certa sincronicidade para encaixarem-se, mesmo sendo realizadas independentemente uma da outra.

Como mencionado acima, isso só foi possível devido ao fato de Souza, de maneira totalmente sem controle e desproposital, incitar em mim e nele a mesma 
fagulha ao propor criarmos sem referencial. Devido ao contexto social em que vivemos e à cultura a qual absorvemos, trechos do desencadear narrativo que cada um deu à própria parte, acabaram por dialogarem de maneira surpreendentemente harmônica.

A primeira página da história, por exemplo, é tão sincronizada que o leitor desavisado a lê e não percebe as coincidências. Logo no primeiro quadro se torna evidente a nossa sincronia: O próprio título que demos: "Agir sem Ver", já serve como início do texto, tendo de fundo um quadro totalmente negro, assim como o ato de não ver. Em seguida o texto: "criar sem saber", a imagem é um detalhe de um rosto estilizado, o qual só se percebe a feição após se deter em uma análise mais apurada. Antes disso, a imagem parece disforme. No terceiro quadro, para me deter em três exemplos da sequência inicial, o texto diz: "para onde ir?", e a imagem abaixo é de um rosto à gritar "NÃO", com expressão de total desespero e pavor. A frase, então, acaba por funcionar como um reforço da imagem, aumentando a agonia da personagem. Esses foram apenas três exemplos, mas durante toda a história tanto o texto como a imagem dialogam entre si de maneira dinâmica quase todo o tempo. Apesar disso, há um ou dois quadros que quebram o ritmo e dão a impressão de que algo não se encaixou adequadamente.

É interessante notar que a motivação para criar não é necessariamente dada de modo consciente. No nosso caso, por exemplo, veio da dúvida em comum. Fato esse que reafirma os "devaneios ou sonhos" como não sendo produtos de acidentes (MAY, 1982, p. 45). Mas, como destaca May (1982) são soluções (ou encontros) possíveis apenas de surgirem nos próprios sonhos ou devaneios, uma vez que a mente usa desses estados de descanso para irromper a ideia incubada no subconsciente para o consciente (MAY, 1982, p. 45). Para May, a partir disso, passa a valer o nível de compromisso do indivíduo com o próprio ato criativo. Ou seja, estarmos dispostos a fazer o que nos propomos, mantendo a dúvida como um dos elementos instigadores. Como resultado, fomos guiados a uma conexão narrativa entre texto e desenho. 


\section{4 - MERREM}

Ao contrário das obras até aqui destacadas, dentro do nosso fazer criativo, MERREM (2011) surge em um novo contexto: o digital. Uma experiência, até o momento, única para nós (os envolvidos), motivada por cada dia mais, no mundo contemporâneo, artistas - e a sociedade em geral - se voltarem para as novas tecnologias. São vários os exemplos que se veem cotidianamente dessa migração, ou melhor, dessa adaptação aos novos meios promovidos pelos avanços tecnológicos. Nas Histórias em Quadrinhos, por consequência, não é diferente.

Com a popularização das tecnologias computacionais, muitos quadrinhístas, em meados de 1980, iniciam experiências de criação de suas narrativas utilizando os recursos que o computador oferecia, primeiramente, para colorizar, finalizar ou letreirar seus projetos. Contudo, aos poucos o objeto impresso deixa de ser o foco, de tais manifestações, e as HQs passam do suporte papel às telas do computador. Nesta transição, destacam-se, ainda, dois momentos importantes: a adaptação dos quadrinhos para CD-ROM, no início dos anos de 1990, e, finalmente, a popularização da rede Internet, a qual possibilita à veiculação de trabalhos on-line e experiências com recursos de hipermídia em tempo real.

O conceito de hipermídia advém do hipertexto e sua estrutura tecnológica que permite o armazenamento de dados e o acesso não-linear a eles. Porém, a hipermídia agrega em si características de várias linguagens como os próprios quadrinhos, o cinema, a fotografia, TV ou rádio, gerando "o surgimento de linguagens multifacetadas que hibridizam características dessas várias mídias" (FRANCO, 2008, p. 145). A hipermídia traz, ainda, em seu cerne a necessidade de interação, reação e escolhas de seu navegador / interator, que tem a sua disposição uma rede de informações conectadas por links clicáveis podendo ser acessadas conforme sua preferência.

As histórias em quadrinhos, então, acabam por assumir características que o meio computacional proporciona, tais como animação, diagramação dinâmica, trilha sonora, efeitos de som, tela infinita, tridimensionalidade, narrativa multilinear e interatividade (FRANCO, 2008). Uma vez que exploram um ou mais recursos citados acima, as HQs tradicionais passam a ser classificadas como HQtrônicas, termo cunhado pelo já citado pesquisador Edgar Franco (2008).

MERREM, então, se enquadra dentro desse conceito de HQTrônicas por 
justamente usar alguns dos recursos tecnológicos mencionados acima. Como produto digital, fruto de coautoria, MERREM foi roteirizada por mim, editada e produzida por Fernanda Machado e ilustrada por pelos artistas Guilherme E. Silveira, Ângelo Ron, Eduardo Spicacci, Caio Majado, Rosemário Souza e Rodrigo Lara. Enquanto HQTrônica, mais precisamente, MERREM explora a "diagramação dinâmica" que emula movimentação nos quadros e dessa forma "efeitos de verticalidade e horizontalidade de requadros podem ser ressaltados fazendo com que os mesmos surjam das laterais ou da parte superior da tela" (FRANCO, 2008, p. 152). Além disso, inclui recursos como as trilhas e efeitos sonoros.

Vale ressaltar que a história, apesar do formato digital, dialoga com um subgênero distinto das histórias em quadrinhos: o Poético-Filosóficos. MERREM, então, se encaixa no gênero poético-filosófica por possuir as três características propostas por Neto (2010) - independentemente do suporte -, de deixar-se aberta para múltiplas interpretações, inovar nos recursos gráficos e levar o leitor a reflexão.

\section{Construção}

Enquanto obra, MERREM surge a partir da necessidade de se criar uma narrativa para a disciplina, do Programa de Pós-graduação em Arte e Cultura Visual da FAV/UFG, Teoria da Arte e da Cultura Visual, ministrada pelo Prof. Dr. Raimundo Martins, da Faculdade de Artes Visuais - UFG. Dessa forma, ambos os alunos do mestrado, Matheus Moura e Fernanda Machado, por pesquisarem histórias em quadrinhos, decidem juntos realizar uma HQtrônica que explore recursos tecnológicos.

A narrativa de MERREM surge a partir da desconstrução de histórias já existentes - tanto inéditas como publicadas - escritas por Moura, mas resignificadas e reorganizadas em um novo roteiro e produção. Além das singularidades já mencionadas, destaca-se por ser um experimento de recortes visuais que acaba por unir em uma única narrativa, diferentes estéticas e estilos de ilustração e artistas. Como mote para chegar a tal estética foi tido o fato de já possuirmos diversas histórias em quadrinhos prontas, as quais poderiam ser deslocadas de seu sentido original a fim de integrar uma nova narrativa. Para isso, decidimos utilizar o material que nós mesmos já havíamos realizado originalmente, para mantermos a perspectiva autoral e não esbarrarmos em questões de direitos 
autorais - uma vez que, apesar de as imagens não serem desenhadas, terem sido criadas a partir de roteiro nosso, ou seja, não deixam de ser, também, nossas criações.

A história, por sua vez, trata de um sonho da personagem principal - a qual não é nomeada. Dessa forma, assim como em um sonho, a mudança de ambientes se torna frequente a guiar a personagem por entre o próprio subconsciente, a caber, então, ao fruidor da HQTrônica distinguir o que é realidade ou não dentro da narrativa proposta.

Quando ao título, MERREM, ele é um palíndromo, ou seja, uma palavra que poder ser lida de trás para frente que possui a mesma leitura e/ou significado. No caso, MERREM é a sigla em inglês R.E.M. duplicada, a qual significa rapid eye movement (movimento rápido dos olhos), e é o quinto estado do sono - no qual ocorrem a maioria dos sonhos, sendo estes os mais vívidos e marcantes para os indivíduos. Devido a isso e a história ser uma sequência de sonhos - e esses cíclicos, como é apontado dentro da narrativa - a sigla foi dobrada, tornando-se um palíndromo e fazendo referência ao símbolo alquímico Oroboro, a serpente que morde a calda e significa o infinito, o eterno retorno.

O já mencionado pesquisador, Stephen Nachmanovitch, violinista, compositor, poeta, professor de artes e psicólogo, no livro Ser Criativo (1993) traça modos de como desenvolver, observar e incentivar o próprio processo de criação tendo como foco a improvisação. (NACHMANOVITCH, 1993, p.18). De maneira geral, em MERREM, o improviso é bastante latente, uma vez que a história foi crida de repente, sem um estudo prévio ou muito racionalizar à respeito - típico surgir de algo determinado como sendo a própria "chave-mestra da criatividade" (Idem, Ibdem, p.18). Outro aspecto que marca a narrativa é o referente ao processo mental e emocional. Para Kneller (1978), é necessário ao individuo criativo certo equilíbrio das faculdades mentais para exercer a criatividade, uma vez que ela necessita ser fundida com a inteligência (KNELLER, 1978, p.22). De modo geral, criatividade e inteligência acabam por ser dois aspectos latentes no resultado final da narrativa MERREM. 


\section{Conclusão}

Como foi possível observar no decorrer deste artigo, nosso fazer criativo depende de certa liberdade. Fato esse que nos propicia experimentações e novas possibilidades estéticas. É a partir de obras assim que a linguagem se renova e avança sobre seus limites. De acordo com a artista Fayga Ostrower, o que impulsiona o indivíduo a essas aventuras é sua sensibilidade. É por meio dela que ele capta as nuances do mundo ao seu redor e traduz suas percepções pessoais e sentimentos na realização artística. A sensibilidade, no entendimento de Ostrower (1977, p.13), não age sozinha sendo complementada por uma série de "capacidades mentais": consciência; memória; associações; formas, ordenações interiores; e tensão psíquica.

Fayga Ostrower elucida o que vem a ser essas "capacidades mentais". Para ela, ao todo, o artista se distingue por estreitar relações com essas capacidades. São elas: a "sensibilidade", que está ligada a percepções, sendo ela "uma porta de entrada das sensações" (OSTROWER, 1977, p.13), ou seja, é a partir daí que se articulam as interações do indivíduo com o mundo ao qual está inserido. A "consciência", que por meio de agentes culturais, representa "a individualidade subjetiva de cada um" (Idem, 1977, p. 17). A "memória", é dela a competência de articular o passado e o presente, dessa forma "integrar experiências já feitas com novas experiências que pretende[-se] fazer" (Idem, 1977, p.19). É por meio dela também que se estabelece as "associações" - outra capacidade citada por Ostrower - por elas comporem "a essência de nosso mundo imaginativo (...) são correspondências, conjecturas evocadas à base de semelhanças, ressonâncias íntimas em cada um de nós com experiências anteriores" (Idem, 1977, p.20). Esse aspecto liga-se diretamente com as "formas e ordenações interiores". Sem elas não haveria como o homem comunicar-se de maneira a se fazer entender pelos outros (Idem, 1977, p.25).

No entanto, a capacidade mental mais importante apontada pela autora talvez seja a "tensão psíquica". A artista plástica não a coloca de maneira direta como sendo a inspiração propriamente dita, mas situa essa tensão próxima ao que Stephen Nachmanovitch coloca como "musa" (NACHMANOVITCH, 1993, p. 43). Ainda para Ostrower, essa tensão seria uma "noção de renovação constante do potencial criador" (OSTROWER, 1977, p. 27). 
Isso porque, para ela, a criatividade funciona como uma habilidade, a qual quanto mais exercitada mais afinada se torna e, assim, mais integrada à vida do indivíduo. "Criar, significa poder sempre recuperar a tensão, renová-la em níveis que sejam suficientes para garantir a vitalidade tanto da própria ação, como dos fenômenos configurados" (OSTROWER, 1977, p. 28). A criatividade, como atividade físico mental pode (e deve) ser exercitada para melhora de desempenho (NICOLAU, 1994, p. 13). Em outras palavras, a criatividade "implica uma força crescente; ela se reabastece nos próprios processos através dos quais se realiza" (OSTROWER, 1977, p. 27).

Mesmo ao entendermos que todas essas capacidades levantadas por Ostrower funcionam em conjunto e sem ordem e importâncias distintas, iremos nos ater em maior medida à "sensibilidade" - até porque vários pesquisadores levantam esse ponto em comum (Gloton \& Clero [1972]; Nachmanovitch [1993]; Kneller [1978]; Salles [2009]). Essa escolha se dá, também, pelo fato de que, fora a sensibilidade, as outras capacidades levantadas pela autora ou estão intrinsecamente ligadas ao indivíduo (consciência, memória, tensão psíquica) ou as próprias vivências dele (associações, formas e ordenações interiores), enquanto sensibilidade é latente dentro do produto artístico. "Se partirmos de uma sensibilidade alerta, afetiva, motivada para determinadas tarefas e dirigida para um fazer específico, essa sensibilidade se basta" (Ostrower, 1977, p. 73), explicita a artista.

Assim, tendo como base a sensibilidade percebemos como ela é latente e vital na realização dos trabalhos aqui analisados. Mesmo a re-interpretação, feita por Carmila, só se tornou realidade devido à sensibilidade da leitora/autora. Mais do que a sensibilidade, podemos identificar nessas obras a expressão do eu, a interação conceitual, o formalismo, o objetivo e a necessidade de comunicação características essas identificadas por Scott McCloud (2005) para determinar HQs autorais/artísticas. Justamente por meio desses sentimentos e necessidades aproximamos os autores analisados ao caráter de legítimos artistas contemporâneos. A diferença deles para qualquer outro artista que trabalhe com as "artes legitimadas" socialmente é meramente conceitual e, não raro, carregada de preconceitos. Para ilustrarmos a questão, cito o exemplo de Lourenço Mutarelli prolífico quadrinhista, romancista, ator e roteirista (de teatro e cinema). De acordo 
com o autor há uma nítida diferença de tratamento entre ele o quadrinhista e ele o escritor literário.

Eu costumo dar como exemplo uma palestra que fiz numa entidade no mesmo mês, em Brasília, uma como quadrinhista e outra como escritor. Como quadrinista eles me colocaram num puta hotel fuleiro, me pagaram um cachê de cento e poucos reais. Aí eu voltei no mesmo mês como escritor e tinha uma van, um super hotel, era quase 2 paus de cachê, me tratavam como se eu fosse alguém (MUTARELLI, 2008, s/p).

Talvez, por essas e outras razões, seja difícil de se aceitar a equidade autoral entre um quadrinhista e outros artistas - independente do meio utilizado. O que, no final das contas, acaba por nos motivar a pesquisar a relevância de nossos próprios processos criativos os quais, como vimos, são tão complexos e necessários a nós como a qualquer outro. Salientamos, ainda que, a depender do ramo artístico, hoje, os processos e conceitualidades das obras quadrinhísticas podem ser dotados, até mesmo, de uma aura com potencial sublimador - de certa forma - maior e mais transformador que muitos filmes, obras literárias ou pinturas contemporâneas.

\section{Bibliografia}

ANDRAUS, G. A autoria artística das histórias em quadrinhos (HQs) e seu potencial imagético informacional. In: Visualidades. Revista do Programa de Mestrado em Cultura Visual/UFG. Goiânia-GO: UFG, FAV, 2009. cap. 2, p. 42-67

ANDRAUS, G. O trabalho com histórias em quadrinhos (HQ) no ensino universitário. In: NETO, E. S.; SILVA, M. R. P. da (Org). História em Quadrinhos \& Educação: formação e prática docente. $1^{a}$ edição. São Bernardo do Campo: Universidade Metodista de São Paulo, 2011. p. 33-55.

ANDROFOBIA. In: Dicionário contemporâneo da língua portuguesa Caldas Aulete. São Paulo. Lexicon, 2012. Disponível em: <http://www.auletedigital.com.br/ >. Acesso em: 21.07.2012.

DANTON, G. Watchman e a teoria do caos. $1^{\mathrm{a}}$ ed. João Pessoa: Marca de Fantasia, 2005.

DANTON, G. O terror no Brasil. Bigorna.net. São Paulo, s/n, jan. 2011. Disponível em: http://www.bigorna.net/index.php?secao=dantonpedia\&id=1295266639. Acesso em: jul. 2012. 
FANU, C. le. Necrofilia ou Uma Reinterpretação de Frígida. Camilla le Fanu. Em: http://carmillalefanu.blogspot.com/. Acesso em: jul. 2012.

FRANCO, E. S. HQtrônicas: do suporte papel à rede internet. $2^{\mathrm{a}}$ ed. São Paulo: Annablume; FAPESP, 2008.

FRÍGIDA. In: Dicionário contemporâneo da língua portuguesa Caldas Aulete. São Paulo. Lexicon, 2012. Disponível em: <http://www.auletedigital.com.br/ >. Acesso em: jul. 2012.

GLOTON, R.; CLERO, C.. La creatividad em el niño. $1^{\mathrm{a}}$ ed. Madrid: Narcea S. A. De ediciones, 1972.

KNELLER, G. F.. Arte e ciência da criatividade. 5a ed. São Paulo: IBRASA, 1978.

LEE, J.. Alan Moore e DC Comics comentam Before Watchmen. UniversoHQ. São Paulo, s/n, fev. 2012. Disponível em: <http://www.universohq.com/quadrinhos/2012/n15022012_05.cfm> . Acesso em: jul. 2012.

LUIZ, C.. EC Comics: o berço dos gibis de horror. Bigorna.net. São Paulo, s/n, agosto. 2010 Em http://www.bigorna.net/index.php?secao=artigos\&id=1282747007. Acessado em: jul. 2012.

McCLOUD, S. Desvendando os Quadrinhos. 1ª ed. São Paulo: M.Books do Brasil Editora Ltda, 2005.

MAY, R. A coragem de criar. $2^{\mathrm{a}}$ ed. Rio de Janeiro: Nova Fronteira, 1982.

MELO, R. M. de. A espada era a lei [manuscrito]: visualidades da práxis pedagógicas. 2008. 98 f. Dissertação (Mestrado em Cultura Visual) - Universidade Federal de Goiás, Goiânia, 2008.

MOORE, A.. Alan Moore e DC Comics comentam Before Watchmen. UniversoHQ. São Paulo, s/n, fev. 2012. Disponível em: <http://www.universohq.com/quadrinhos/2012/n15022012_05.cfm> . Acesso em: jul. 2012.

MOURA, M; SOUZA, R.. Agir sem Ver. Camiño di Rato, Uberlândia, n. 2, p. 11-14, segundo semestre. 2009.

MOURA, M; SOUZA, R.. Frígida. Camiño di Rato, Uberlândia, n. 3, p. 39-40, primeiro semestre. 2010.

MOURA, M. Encontro. Encontro, Uberlândia, s/n, p. 2-4, junho. 2010.

MUTARELLI, L.. A estranha arte de produzir efeito sem causa. [20 de agosto, 2008]. São Paulo: Psicanálise e Cultura; v.31 n.47 p.170-179. Entrevista concedida a Cláudio Rossi.

NACHMANOVITCH, S.. Ser criativo - o poder da improvisação na vida e na arte. $1^{\mathrm{a}}$ ed. São Paulo: Summus, 1993. 
NICOLAU, M.. Introdução à criatividade. 2ª ed. João Pessoa: Idéia, 1994.

OSTROWER, F. Criatividade e Processos de Criação. $1^{\mathrm{a}}$ ed. Rio de Janeiro: Editora Vozes, 1977.

SALLES, C. A. Gesto Inacabado: processo de criação artística. $4^{a}$ ed. São Paulo: FAPESP: Annablume, 2009.

SANTOS NETO, E.. As histórias em quadrinhos poético-filosóficas no Brasil: Origem e estudo dos principais autores numa perspectiva das interfaces educação, arte e comunicação. 2010. 205 f. relatório (Pós-Doutoramento em Artes) - Universidade Estadual de São Paulo, São Paulo, 2010.

SILVA, N. M. da. Fantasias e Cotidiano nas Histórias em Quadrinhos. $1^{\mathrm{a}}$ ed. São Paulo: Annablume, Fortaleza: Secult, 2002.

SILVEIRA, G. E. Processo. In: SILVA, M. M. (Org.) Encontro. Uberlândia: Fanzine/Edição do Autor, 2010

SOUZA, R. Entrevista concedida a Matheus Moura Silva. In: Anexo de E-mail de Rosemário Souza para Matheus Moura Silva, em 13 de abril de 2010.

SWING. In: Dicionário contemporâneo da língua portuguesa Caldas Aulete. São Paulo. Lexicon, 2012. Disponível em: <http://www.auletedigital.com.br/ >. Acesso em: jul. 2012.

WAHBA, L. L.. Criatividade, inspiração, possessão e arte. In: PINTO, G. C. (Org). Coleção memória da psicanálise - Carl Gustav Jung. 2 a ed. São Paulo: Duetto Editorial, 2009. p. 82-89.

VYGOTSKY, L. S. La imaginación y el arte em la infancia (Ensayo psicológico). $1^{\mathrm{a}}$ ed. Madrid: Akal Editor, 1982. 